\title{
Analysis of Factors Associated to the Enrollment and Demand of Computing-Related Careers
}

\author{
Walter Alexander Mata-López ${ }^{1, *(\mathbb{D})}$ and Sergio Tobón ${ }^{2} \mathbb{D}$ \\ 1 Faculty of Electrical and Mechanical Engineering, University of Colima, Km. 9 Carretera \\ Colima-Coquimatlán, Coquimatlán C.P. 28400, Mexico \\ 2 Doctorado en Socioformación y Sociedad del Conocimiento, Centro Universitario CIFE (CIFE University \\ Center), C. Tabachín No. 514, Col. Bella Vista, Cuernavaca C.P. 62140, Mexico; stobon@cife.edu.mx \\ * Correspondence: wmata@ucol.mx
}

Received: 29 July 2018; Accepted: 18 December 2018; Published: 20 December 2018

\begin{abstract}
Despite the great need for computer-related career professionals, some universities that offer specialties to develop professionals with knowledge to cover the mention need, present a decrease in enrollment, which can cause a wide variety of problems. That is why in this paper we set out to investigate what the main factors that directly or indirectly affect student enrollment in computer-related careers are, to establish a literature-based starting point, and to help select the best possible strategy to improve enrollment. To reach this goal, we did a documentary research, categorizing each one of the factors with its respective analysis. In the results, we explain several challenges that educators face, due to the evolution of society needs, two of them are: teaching-learning models and technology; besides, it became evident that the relevance of this academic programs remain available since there is a high demand for these professionals in Mexico, as well as in the world; finally, we showed some intrinsic and extrinsic motivational factors that have an essential relevance at the time that a student chooses the career to study. On the other hand, we reflected that the perception of everything that involves the study of a Computing-related career is a factor to be considered in the selection of an educational program of higher education. This study could be a reference for universities that are facing decreasing enrollment concerns. In conclusion, we analyzed and identified the main factors that have an impact on the demand for a career related to engineering, providing possible lines of action for increasing school enrollment.
\end{abstract}

Keywords: educational demand; higher education; systems engineering; information technology; computer science; computing-related

\section{Introduction}

Computers and information systems have become very important in today's life. The applications of these information technologies are extensive, to the point that the universities that offer computer-related careers have created subspecialty curriculums to offer the different academic profiles that industry and society demand.

There are several types of computing-related careers: Computer Science, Computing Systems Engineering, Computer Engineering, Information Systems, Information Technology, among others. These careers are no longer exclusive to a region, state or country, they are global thanks to the current mass media enabling teleworking (Contreras and Rozo-Rojas 2015), thus saving considerable resources by not needing to move to a place of employment physically. The academic offer in the area of computing has increased both, in the number of careers, and public and private institutions, which causes college students to have more options to choose where to study. If they do not choose adequately, the phenomenon of desertion or abandonment can occur, which becomes a critical educative issue. 
Regardless the reason for the abandonment or lack of interest to enroll in a computer career, the problem in a quantitative way for institutions of higher education is to increase the enrollment.

There are several research studies related to the professional aims of teenagers in different cultures, finding both intrinsic (cognitive ability, affective and physical attributes), and extrinsic (economic and social circumstances) common motivational factors that influence career choices (Alexander et al. 2011). In addition, perception is an important aspect to consider; according to the Royal Spanish Academy (2014), perception is the sensation that a person has when relating material aspects to the senses. The perception that students have of the career, the university, the professors, the students, and so on, is remarkably crucial for them to make a decision in the selection of career, because it is in what they intend to work the rest of their lives, and which will allow them to satisfy all their needs and achieve a fulfilled life.

Furthermore, it is essential to find out the reasons why some higher education institutions have problems to complete or maintain their enrollment in demanded computing-related careers (Alexander et al. 2011; Belanger et al. 2007). The problems of decreasing enrollment, desertion or failure, leads a series of problems that affect the entire educational community (Bossart and Bharti 2018; Cozzolino et al. 2018; Declercq and Verboven 2018). With no students, there are fewer class groups and fewer teachers needed, so it may be necessary to reduce the teaching staff or, assign them to other types of activities rather than teachings, such as management and diffusion. Moreover, regardless of the number of students, the administrative and service staff is kept in quantity, since the installations remain the same and need the same maintenance. Getting to know the factors that affect the enrollment and possible strategies to implement, university authorities will be able to keep the academic, administrative and service staff, providing citizens with an adequately chosen and distributed education for the social and productive sectors.

In order to know which factors are related to the demand for computer-related careers, we focused the present documentary study on the following goals: (1) analyze the demand and relevance of computer systems engineering and trends towards the future in Mexico; (2) analyze the different factors that influence the demand for engineering careers, both in terms of their increase and decrease; (3) analyze successful experiences in the improvement of enrollment in engineering careers; and (4) establish strategies to improve the demand for the computer systems engineering career.

The rest of this paper is structured as follows: in Section 2 we describe the methodology used to carry out the documentary analysis of computing-related careers factors; defining the type of study, the category of analysis, the document selection criteria and the documents selected. In Section 3 we show the results obtained by the six categories of analysis previously defined. Finally, in Section 4 we show a set of conclusions about documentary research.

\section{Methodology}

\subsection{Type of Study}

Following the aim of the present research, a documentary analysis was carried out to analyze the factors related to the demand for careers in the field of computer systems engineering. In agreement with Bernal (Bernal 2010), research of this type analyzes the information that exists on a given subject, to determine relationships, differences, stages, positions or the current state of the art concerning the subject under study. In the same way, del Cid, Méndez, and Sandoval (Del Cid 2011) confirm that the documental research techniques are geared towards obtaining previously written information, enriching the theoretical research framework with the background and facts that have occurred about the subject under consideration. On the other hand, Hernández-Sampieri et al. (Hernández-Sampieri et al. 2014) indicate that one of the stages for the development of the theoretical perspective is the literature review, which involves the detection, consulting and obtaining of bibliographic references and any other material that is useful for the research issue. The need for the present research was justified determining the 
following: what types of documents need to be analyzed, where they can be found, what the selection criteria is, as well as the necessary process to carry out the analysis under the established goals.

\subsection{Categories of Analysis}

We analyzed the literature, and after exhaustively reviewing it, we determined the main factors that affect the demand or enrollment for university careers; thus, each of these factors was considered within one of the six categories of analysis described in Table 1.

Table 1. Analysis of Categories Employed in the Study.

\begin{tabular}{ll}
\hline \multicolumn{1}{c}{ Categories } & \multicolumn{1}{c}{ Questions or Components } \\
\hline $\begin{array}{l}\text { Challenges of the knowledge society and } \\
\text { socioformation for university careers }\end{array}$ & $\begin{array}{l}\text { What are the challenges of socioformation and } \\
\text { knowledge society in the engineering career sector? }\end{array}$ \\
\hline $\begin{array}{l}\text { Relevance and demand of computer systems } \\
\text { engineering and future trends in Mexico }\end{array}$ & $\begin{array}{l}\text { Despite of being one of the first careers in } \\
\text { computer science, is curricular Computer Systems } \\
\text { Engineering in Mexico able to face the challenges } \\
\text { of knowledge society? }\end{array}$ \\
\hline $\begin{array}{l}\text { Factors associated with the demand for } \\
\text { engineering careers }\end{array}$ & $\begin{array}{l}\text { Which factors determine the demand for } \\
\text { engineering careers? }\end{array}$ \\
\hline $\begin{array}{l}\text { Successful experiences that improve demand for } \\
\text { university and engineering careers }\end{array}$ & $\begin{array}{l}\text { Are there successful experiences in improving the } \\
\text { demand for engineering careers? }\end{array}$ \\
\hline $\begin{array}{l}\text { Strategies to improve the demand for computer } \\
\text { systems engineering career }\end{array}$ & $\begin{array}{l}\text { What strategies can be implemented to improve the } \\
\text { demand for computer systems engineering careers? }\end{array}$ \\
\hline $\begin{array}{l}\text { Perception of the quality of engineering } \\
\text { education programs }\end{array}$ & $\begin{array}{l}\text { Is the students' perception of engineering } \\
\text { education programs important? }\end{array}$ \\
\hline
\end{tabular}

\subsection{Document Selection Criteria}

The criteria considered for the selection of the documents are the following:

1. The search for papers and books was carried out using mainly the following databases: WoS, Scopus, Science Direct, Scielo, Redalyc, Latindex, IEEE, and Google Academic.

2. Several keywords were used in English and Spanish to search for bibliographic references; most of these were combined to obtain more refined results. These words were: "selection factors", "career", "engineering", "perception", "desertion", "abandonment", "motivation", "computing", "enrollment", "information technology", "informatics", and "computer sciences".

3. The selection was only from papers published in indexed journals, books of recognized publishers, research centers or prestigious universities.

4. The documents mainly cover the period 2013-2018, due to that during this period we found significant references for the subsequent selection and analysis.

5. The documents selected addressed some element of the previously established categories for the proposed documentary research.

\subsection{Documents Selected for Analysis}

Table 2 presents a summary of the number of documents selected for the analysis in this study. Table 3 shows the distribution of this documents by continent, and as it is possible to observe, in the American continent and Europe mainly the most significant studies were found concerning the proposed research topic. Of all the selected documents, $78 \%$ were written in English and the remaining $22 \%$ in Spanish. 
Table 2. Summary of the Documents Analyzed in the Study.

\begin{tabular}{ccc}
\hline Documents & About the Subject & Contextualization or Complementary \\
\hline Theoretical papers & 57 & 2 \\
Books & 3 & 5 \\
Manuals & 5 & - \\
\hline
\end{tabular}

Table 3. Summary of the Documents Classified by Continent.

\begin{tabular}{cccc}
\hline Africa \& Oceania & America & Asia & Europe \\
\hline $3 \%$ & $64 \%$ & $7 \%$ & $26 \%$ \\
\hline
\end{tabular}

Table 4 presents a percentage summary of the documents selected by year, as we can see, the majority of them are from 2014 through 2018 with $86.43 \%$ of them.

Table 4. Summary of the Documents Classified by Year of Publication.

\begin{tabular}{cccccc}
\hline $\mathbf{2 0 1 8}$ & $\mathbf{2 0 1 7}$ & $\mathbf{2 0 1 6}$ & $\mathbf{2 0 1 5}$ & $\mathbf{2 0 1 4}$ & $\mathbf{2 0 1 3 - 1 9 9 9}$ \\
\hline $25.70 \%$ & $4.50 \%$ & $15.20 \%$ & $22.80 \%$ & $18.23 \%$ & $13.57 \%$ \\
\hline
\end{tabular}

Only $19 \%$ of the research articles selected were written in Spanish, the number of citations made for this articles reached a total of 291, and in English 81\%, representing a total of 746 citations reached, all this information taken from the Google Scholar Citations site. In Table 5 we can see the year-by-year breakdown of total citations that were generated by the research papers analyzed.

Table 5. Summary of Citations by Year of Publication in Google Scholar Citations.

\begin{tabular}{ccccccccccc}
\hline $\mathbf{2 0 1 8}$ & $\mathbf{2 0 1 7}$ & $\mathbf{2 0 1 6}$ & $\mathbf{2 0 1 5}$ & $\mathbf{2 0 1 4}$ & $\mathbf{2 0 1 3}$ & $\mathbf{2 0 1 2}$ & $\mathbf{2 0 1 1}$ & $\mathbf{2 0 0 8}$ & $\mathbf{2 0 0 7}$ & $\mathbf{1 9 9 9}$ \\
\hline 6 & 6 & 137 & 169 & 113 & 164 & 238 & 72 & 92 & 25 & 15 \\
\hline $0.53 \%$ & $0.53 \%$ & $13.24 \%$ & $16.34 \%$ & $10.91 \%$ & $15.86 \%$ & $23.03 \%$ & $6.93 \%$ & $8.87 \%$ & $2.37 \%$ & $1.39 \%$ \\
\hline
\end{tabular}

\subsection{Study Limitations}

Initially, we searched for the topics in question in the first two years in the databases previously mentioned, as we did not find a considerable amount of literature, this was extended to other years allowing us to increase the documents found. If this period extends further, it would be possible to find other investigations that could contribute to this research, although the phenomenon of decreasing enrollment at that moment would not respond to the same current social conditions. On the other hand, the majority of documents selected for analysis have been found in the American and European continents (88\%), the first of which is $59 \%$ (Table 3$)$, giving a clear indication of the concern of these countries about the subject in question.

\section{Results}

The results presented below are written according to the six categories previously described, each of the factors found and analyzed is contained in one of these categories.

\subsection{Category 1. Challenges of the Knowledge Society and Socioformation for Academic University Programs}

According to Webster (2006), an information society or knowledge society "is defined as one in which theoretical knowledge occupies a pre-eminence which it hitherto lacked" (p. 26). In this category we show the importance of the knowledge society in the educational field, some of the challenges of incorporating new technologies into learning environments, and that socioformation can be integrated to improve the knowledge society by allowing the integral seeking of human development. 
Tobón (2018) did a documentary analysis to analyze and determine the knowledge society concept from the humanist point of view, among other things he established that it is not defined as the use of Information and Communication Technologies (ICT) itself, but it refers to a substantial change in order to seek integral human development through the process of developing better ways of coexistence, economic development, and environmental sustainability through continuous collaborative projects; which in addition allow the creation of new knowledge based on ethics and universal values, this precepts establishes the bases of the socioformative approach (Tobón 2016).

In the knowledge society, education (in its formal or informal modality) plays a significant role in the economic, political and social development. As stated by Vali (2013), information has value only if it is known where to find it, what to do with it, how to select it and how to integrate it into a system; talking about tacit and explicit knowledge, which difference lies in the possibility of transferring it. Formal education systems are responsible for preserving knowledge throughout the new generations regardless of their characteristics, in terms on quality and quantity.

Mayes, Natividad y Spector (Mayes et al. 2015) present challenges for technological educators in the current century, challenges that involve the integration of new technologies into educational systems and learning environments. Table 6 shows the five challenges presented in his research.

Table 6. Challenges of Technological Educators.

1. Prepare and maintain a team of competent technological educators.

2. Plan and organize project processes.

3. Systematically identify the requirements of the integration of educational technology.

4. Redefine and refine teacher roles.

5. Manage resources, in addition to provide maintenance and support.

The challenge of preparing and maintaining a team of competent technology educators is addressed by Ciolan et al. (2014), saying that teachers are the most crucial elements in a knowledge society, in the sense that in a learning society, it is necessary to be lifelong learners, since every day they try to solve problems, share ideas, and understand situations. The knowledge society not only presents challenges for the new generations, people who did not receive education according to this new social reality, may have problems to addapt to new technologies, so it is necessary to design or develop appropriate learning environments in workplaces to achieve better integration. In the study proposed by Ngamkajonviwat et al. (2015), they propose a design of an instructional system for educating workers in three industrial factories in Thailand, in a multicultural and knowledge-based society. To achieve this design they presented a series of objectives designed to improve the quality of life of workers, which are: (1) to study the fundamental information and knowledge related to the education of workers, the multicultural society and the knowledge-based society, all with the aim of improving their quality of life; (2) to design an instructional system model for the education of workers; and (3) to propose a model of learning innovation to increase the skills of workers.

A knowledge-based society brings with it new organizational systems based on existing technology: the transfer of scientific knowledge goes from traditional print to electronic media, according to era. In this sense, Kornienko (2015) emphasizes the importance of networked technologies in scientific research and the professionalization of education; he proposes that a new form of science organization is cyber-science, which is artificially created by the automatic system of scientific knowledge, it is considered a research as a service.

Thus, teaching-learning models in the knowledge society evolve according to the technology used: from paper to networked electronic media, which offer multiple options that depend on the resources available in the institutions. A study analyzing the evolution of the Web is presented by Pattnayak and Pattnaik (2016). In this study they describe how Web 2.0 tools and technologies are used in e-learning systems, helping to create personal learning environments and allowing people to collaborate with each other by getting involved in content creation and new knowledge. On the other 
hand, Web 3.0 is considered to be the semantic web, which gives a turn to educational models through the use of artificial intelligence techniques, intelligent interfaces, data mining, big data, among others.

In agreement with Tobón (2017), socioformation provides some essential characteristics that contribute significantly to the formation of human being, so that, it can be effectively integrated into the knowledge society, having as its principal purpose the ethical project of life through entrepreneurship, collaboration, co-creation of knowledge and metacognition. It is not enough to learn and use technology but to have the knowledge, skills, and attitudes to use them appropriately for a fully realized knowledge society.

\subsection{Category 2. Pertinence and Demand of Computer Systems Engineering and Trends towards the Future}

In this category, we present how in different countries the demand for IT professionals is increasing, requiring specific knowledge, skills and attitudes, which must be covered by educational institutions. Specifically, from Mexico, we present the reference frameworks of two organizations that accredit computing-related careers.

Globalization and the growing technological development are increasing the demand for engineering professionals (Pažur et al. 2017), and this demand can be determined by knowing the needs of the labor market regarding the series of knowledge and skills needed by graduates. Furthermore, it is essential that the profile of teachers fit the academic program in which they participate. Todorescu, Greculescu, and Popescu-Mitroi (Todorescu et al. 2015) developed a research that aimed to analyze the importance of the profile of the English teacher, as a driving force for linguistic performance, choice of engineering careers and guarantee of employment. They generally conclude that the professionalism and communication skills of the English teacher can help students to choose for a profession or engineering job. At present, one of the requirements in practically all the works related to Information Technology (IT) is that the professional can communicate in the English language. It is not enough to read or write, because reading and writing in the course of the career are given because most of the documentation of computer programming languages are in English.

We have said that there is a great need for IT specialists in the world, particularly in Russia, there is a shortage of IT professionals, since by 2020 they plan to recruit at least 600,000 IT specialists, and Russian universities graduate about 25,000 students each year (Stanko et al. 2014). In contrasts, in Mexico, the results obtained in a study carried out by the Alianza FiiDEM, A.C. (Alianza 2014), show that the number of graduates from computer science and informatics for the period 2015-2020 is 202,630 professionals against a demand of 34,099, exceding in 168,531 engineers.

At the Faculty of Science and Technology, Suan Sunandha Rajabhat University in Bangkok, Thailand, they recognized the importance of new IT because their graduates not only work as programmers and mathematicians but also as data analysts and business intelligence analysts. These skills are not included in the curricula, so they designed an additional program to prepare them with skills related to data science and big data (Bussaban and Waraporn 2015).

On the other hand, two organizations in Mexico accredit careers related to computer science and computing: (1) the Consejo Nacional de Acreditación en Informática y Computación, A. C. (CONAIC); and (2) the Consejo de Acreditación de la Enseñanza de la Ingeniería, A. C. (CACEI). These organizations are an excellent starting point for knowing the trends in information technology, according to the reference frameworks established for the certification of careers related to computer systems. The curricular profiles considered by CONAIC (2013) are Bachelor in Informatics, Software Engineer, Bachelor in Computer Science, and Computer Engineer. Such profiles establish a framework of reference carried out in 2013, in which they measure the different careers using units to make a comparison, defining as unit $1 \mathrm{~h}$ of theory or $3 \mathrm{~h}$ of group practice. The careers are divided into three knowledge areas, as can be seen in Table 7, detailing specifically the informatics and computing areas in Table 8. If an institution wishes to certify its career and the name does not belong to any of the careers, it has the opportunity to classify it in one of the profiles that best fits. 
Table 7. General Area.

\begin{tabular}{cc}
\hline Knowledge Area & Minimum Units \\
\hline Social sciences, humanities and others & 300 \\
Mathematics and basic sciences & 420 \\
Informatics and computing & 1000 \\
Total minimum program units & $\mathbf{1 7 2 0}$ \\
\hline
\end{tabular}

Table 8. Informatics and Computing Area. (A) BA in Informatics, (B) Software Engineer, (C) BA in Computing Sciences, (D) Computing Engineer.

\begin{tabular}{ccccc}
\hline Area of Knowledge & A & B & C & D \\
\hline Social Environment & 300 & 125 & 100 & 100 \\
Mathematics & 100 & 125 & 250 & 175 \\
Computer Arquitecture & 50 & 75 & 100 & 175 \\
Networks & 75 & 75 & 100 & 150 \\
Base Software & 75 & 75 & 100 & 125 \\
Programming and Software Engineering & 175 & 200 & 225 & 175 \\
Treatment of Information & 175 & 200 & 75 & 50 \\
Human-Machine Interaction & 50 & 100 & 75 & 50 \\
Total Minimum Units & $\mathbf{1 0 0 0}$ & $\mathbf{1 0 0 0}$ & $\mathbf{1 0 0 0}$ & $\mathbf{1 0 0 0}$ \\
\hline
\end{tabular}

CACEI is an organism that certifies engineering careers in general, the degree that they certify with the reference framework CACEI (2014) is Computer Engineering, in which they establish five groups of subjects by knowledge area (see Table 9). The engineering area is divided into subject groups as shown in Table 10, where each of these groups has specific minimum contents within the framework mentioned above.

Table 9. Computer Systems Engineering Areas.

\begin{tabular}{cc}
\hline Knowledge Area/Subject Groups & Minimum Hours \\
\hline Basic Sciences & 800 \\
Engineering Sciences and Applied Engineering & 1300 \\
Social Sciences and Humanities & 300 \\
Other Courses & 200 \\
Total minimum hours & $\mathbf{2 6 0 0}$ \\
\hline
\end{tabular}

Table 10. Detail of Engineering Areas of Computer Systems Engineering.

\begin{tabular}{lll}
\hline \multicolumn{1}{c}{ Basic Sciences } & \multicolumn{1}{c}{ Engineering Sciences } & \multicolumn{1}{c}{ Applied Engineering } \\
\hline - Mathematics & - Computer Science & - Digital Systems Architecture \\
- Physics & - Software (Programming Systems) & - Artificial Intelligence \\
- Chemistry & - Hardware (Electronic Systems) & - Teleinformatics \\
& - Communications & \\
& - Systems, Signals and Control & \\
\hline
\end{tabular}

As it has been mentioned, IT advances rapidly, and the profiles presented by the accreditation institutions mentioned as CACEI and CONAIC are still in the process of updating to satisfy the demands of industry and society. Higher education institutions have to meet different established profiles if they want certification and therefore be able to participate in obtaining federal resources. The problem of the curricular profile in the computing area is adequately addressed by CACEI (2018) in its new reference 2018 framework, which presents a more accurate profile for current needs, although we should say that it is still challenging to keep up with technological advances. This novel proposal for evaluation of new curricula presents six axes for engineering programs with a minimum of hours; 
Table 11 presents these axes, which add Design and Engineering in Axis 3 and add an Economic Administrative Sciences in Axis 5, maintaining the same number of hours of the 2014 framework.

Table 11. Engineering Axes (CACEI).

\begin{tabular}{lc}
\hline \multicolumn{1}{c}{ Knowledge Area/Subject Groups } & Minimum Hours \\
\hline Axis 1. Basic Sciences & 800 \\
Axis 2. Engineering Sciences & 500 \\
Axis 3. Applied Engineering and Engineering Design & 800 \\
Axis 4. Social Sciences and Humanities & 200 \\
Axis 5. Economic Administrative Sciences & 200 \\
Axis 6. Other Courses & 100 \\
Total minimum program hours & $\mathbf{2 6 0 0}$ \\
\hline
\end{tabular}

In this new framework of reference, computation is located in area 5 and presents three profiles for Computer Engineering: (1) Information Systems, (2) Hardware, and (3) Software. The distribution of axes 2 and 3 of the new profiles is quite extensive, so it is recommended to refer to the organism's website for a detailed analysis; it is enough to mention that there are areas as current as mobile computing, big data, WEB programming, cloud computing, robotics, internet of things, video games, business intelligence, among others.

At the beginning of the millennium, Burns (2002) classified computer career opportunities basically into two categories: (1) careers within the computer industry and (2) outside the industry. It is interesting to look at these categories because they are sufficiently inclusive to classify emerging IT, helping to understand the importance of trends in computing-related career opportunities. Table 12 shows this categorization with employment opportunities in general terms. Some of the opportunities presented in that research and development have provided a large number of hardware and software products that are used and exploited commercially.

Table 12. Employment Opportunities within Computer Industry Careers.

\begin{tabular}{l} 
Within the Industry \\
\hline - Hardware Product Development \\
- Software product development: Software engineering, product equipment, systems software \\
programming, engineering and/or scientific applications programming, commercial software \\
development, development manager, product manager. \\
- Research and development: VLSI circuits, neural networks and intelligent systems, natural language \\
processing and speech recognition, image processing and pattern recognition, expert systems and \\
knowledge engineering, multimedia and hypermedia, human-computer interaction. \\
- Employing in a start-up company \\
- Marketing and sales
\end{tabular}

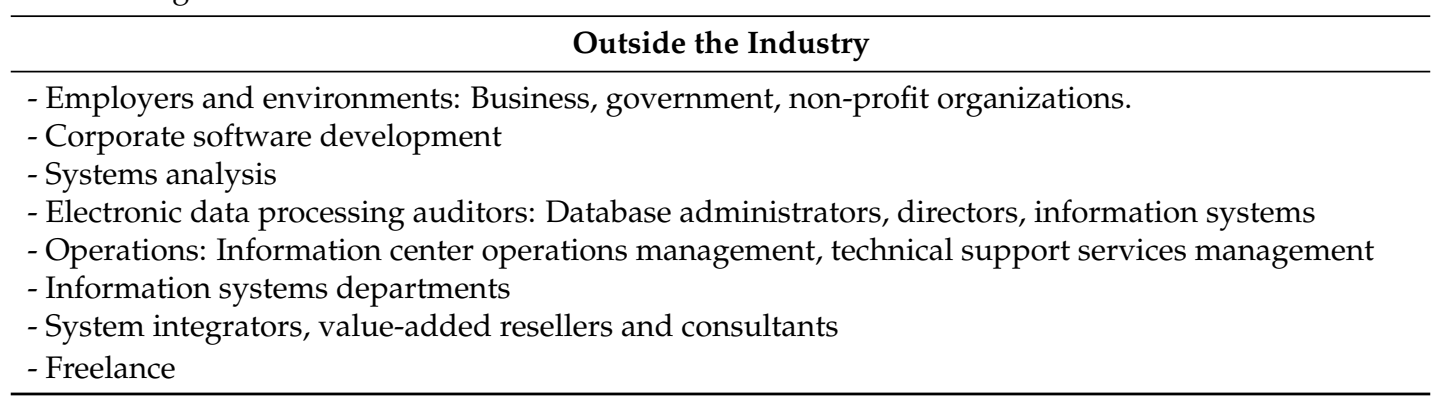

Concerning coverage of educational programs for the software engineering industry in Mexico, Muñóz et al. (2016a) present a three-step methodology to evaluate the coverage of these programs: (1) Moprosoft analysis (Oktaba and Vázquez 2008), (2) description of the ANIEI curriculum model, and (3) coverage assessment. According to the results obtained, the coverage in general terms with the Moprosoft categories is of medium grade (operation and maintenance $52 \%$, managerial $25 \%$, 
and operation $23 \%$ ), emphasizing that with the analysis carried out, it is possible to create a studies program with an ideal curriculum with greater coverage by including specific subjects detected as necessary. In a more extensive work, Muñóz et al. (2016b) evaluated the curricula of 10 Mexican universities under the standard Moprosoft, applying a serie of surveys to 32 small and medium-size companies to contrast the results. They conclude mainly that the study allowed highlighting the best practices in software engineering to be taken into account in improving the curriculum, in addition to collecting a series of knowledge and skills that companies expect to find in recent graduates.

\subsection{Category 3. Factors Associated with the Demand for Engineering Careers}

This category presents, through a series of studies presented in the literature, the different intrinsic and extrinsic motivational factors that they identified as important to the demand for engineering careers. In educational terms, intrinsic motivation refers to the motivation of the student to engage in activities for its own sake, whereas extrinsic motivation is the motivation to participate in an activity as a means to an end (Schunk et al. 2008). Intrinsic factors include, among others, personality, abilities, expectations, and perceptions. Within the extrinsic factors are socioeconomic status, cultural background, school curriculum, teacher attitudes and subject support, and others.

Numerous studies address the various factors related to the preference for enrollement in undergraduate studies (Korkmaz 2015; Wright 2017; Rodríguez et al. 2018; Jiang et al. 2018; Kuba et al. 2018; Fernandes 2018). Korkmaz (2015) mentions that multiple studies have been conducted concerning the professional aspirations of adolescents in different cultures, finding some common intrinsic and extrinsic factors that influence career choice. The most critical intrinsic factors found in Turkish students as reported by (Korkmaz 2015), are gender, personality, abilities, expectations, and perceptions and motivational influences; whereas for extrinsic factors were socioeconomic status, cultural background, school curriculum, teacher attitudes and subject support, parental attitudes and values, and society's perception of occupations. In the study, they considered gender as one of the essential intrinsic factors, as Turkish adolescent girls generally lacked interest in careers and professions related to science and technology. Due to the importance that perception can have in the choice of a university career by students, in Section 3.6 we are going to present the issues related to this factor as a category of study per se.

According to (Alexander et al. 2011; Kozak 2019), the number of students enrolling in computing-related courses is a matter of worldwide concern. Alexander et al. (2011) apply and compare the results of a survey related to career choice for new students of two groups of South African universities, by means of some components of the Social Cognitive Career Theory (SCCT). The actors showed under this theory are three: (1) computer self-efficacy, (2) computer career outcome expectations, and (3) sources of advice. For the first factor, the results showed that the performance of high school courses is more important than that college courses. In the second factor, they found it was more critical the opportunities to work in different types of businesses and job security. Finally, the third factor, the advice of a friend or family member working in a similar career, parents and the University's Open House are more important.

Similarly, in the works of Mangu et al. (2015) a longitudinal research was conducted to determine motivational factors that influence high school students in grades 9-11 to choose careers related to Science, Technology, Engineering and Mathematics (STEM). Students were classified into four categories of intention, showing results that, from ninth to eleventh grade, students changed their purpose: in this two-year period, some students who were interested in the area changed their minds and vice versa. The authors considered, by way of speculation, that the experience in science and mathematics acquired in class, the support of parents and extracurricular activities, largely determine their motivation for career choice.

Once the student has chosen a university career in general, he or she may abandon it for several factors, which are independent of those that led the student to choose it. Is important to detect this factors to be able to work on them, and thus prevent and deal with them. To mention some examples 
of researches related to abandonment, we have the studies of Marra et al. (2012), they found three factors that impact on the decision to abandon engineering studies: academic factors include poor teaching and advisory services, as well as the difficulty of the engineering curriculum; non-academics, on the other hand, found a lack of career belonging. These three factors can be considered to find a solution to desertion and lack of interest in accessing higher education in computing-related careers.

There is also the phenomenon of abandonment of the area studied once the university career is finished, this approach allows to know other factors that could relate to the abandonment during the studies of the career. For this case, in the study conducted by Hunt (2016) highest abandonment rate was found that in engineering rather than science and that women in engineering are less satisfied with pay and promotion opportunities; on the other hand, issues related to family and dissatisfaction with working conditions take second place. For the research, the author used the 2003 and 2010 National Survey of College Graduates to investigate why women with higher degrees in either science or engineering cease to do work related to these areas at higher rates than men with similar qualifications.

The vast majority of engineering students and graduates are male, so there is a considerable amount of research focused on determining the possible factors or causes that make this phenomenon to happen (Marra et al. 2012; Álvarez-Lires et al. 2014; Stanko et al. 2014; Kori et al. 2016; Lee et al. 2017; Oo et al. 2018; Olmedo-Torre et al. 2018). In the study of Álvarez-Lires et al. (2014), the authors analyzed the reasons of students' disinterest or aversion to engineering careers in Galicia, Spain, through the use of questionnaires, interviews and discussion groups; they found in the results, as in the works of Marra et al. (2012), that there are mainly problems of teaching science and technology subjects, causing them to avoid choosing engineering careers. In addition to this, they realized that women do not follow the parameters of men's interests, they do not like abstract things related to mathematics subjects and mostly gender stereotypes that have the perception that women are not for engineering.

Factors found by Kori et al. (2016) that influence the motivation to start and continue studying IT in Estonia are five: (1) the previous personal contact with IT, (2) the reputation of the IT field, (3) both personal and IT development, (4) the desire to continue the previous IT studies, and (5) the learning environment. They consider these factors to be necessary for developing new interventions that increase students' interest in IT, likewise their enrollment and retention.

There are studies such as Stanko, Zhirosh, and Krasnikhin (Stanko et al. 2014), where qualitative research was carried out employing interviews with a focal group, to investigate the reason why women who have an interest in IT issues in high school do not choose an IT-related career. They conclude that to increase the number of women in IT careers, they propose a series of steps giving the justification for each of them, which are: educate the parents, provide additional support to the women during their studies and ensure that they have a university environment that is friendly to women.

\subsection{Category 4. Successful Experiences in Improving Student Enrollment in University Careers}

In a high-tech society, universities need, among other things, to offer innovative academic programs to improve students demand. There are important aspects of evaluating in an educational institution: the quality of the curricula, the facilities, the equipment, the environment, the follow-up of graduates, and so forth. These assessments will allow us to find opportunities to improve enrollment; however, so far few studies have been found in the literature that shows successful experiences in this improvement, which is why documentary research such as the present one can help to establish the basis for future research, so in this category, we present some research that present their experience in developing and implementing strategies to increase enrollment.

The modernization of the Elite Engineering Education Programme (EEEP) conducted by Zamyatina, Mozgaleva, and Gulyaeva (Zamyatina et al. 2014) at Tomsk Polytechnic University, following the Conceive-Design-Implement-Operate (CDIO) standards, enabled students to develop a range of interpersonal skills, professional competencies, and personal qualities. These skills help them to integrate into the world of work in a short period of adaptation, thanks to participation in real-world projects. While the actions described in this category, despite not being studies that present 
results of demand improvement, allow us to appreciate that the adequate design and implementation of programs or activities benefit engineering-related careers in some way.

On the other hand, at the Higher Technological Institute of Irapuato in Mexico, an enrollment projection for the engineering career in Informatics was made, in order to analyze the academic infrastructure, considering the guidelines of CONAIC (Villegas et al. 2015); it was found that if 93 students were admitted in the year of study, in three years the estimated enrollment would be 63 students. In the paper, they do not contemplate actions to revert this poor result, but they did find that the computer equipment and bibliographic collection is not sufficient.

Furthermore, the proposal of Estrada-Danell et al. (2016) to use data mining techniques to optimize the student recruitment process by designing a predictive model, is interesting since they consider variables such as high school average, source school segment, a percentage of scholarship assigned, and the first choice of both career and university indicated. The information to fill in the database to which they applied a decision tree algorithm, was obtained from the different promotional activities of their careers (such as visits, fairs, and advertising). The results obtained allowed them to conclude that the prediction technique used is adequate to generate the enrolment prediction model; they recommend that each institution construct its management model, starting with small populations to evaluate their performance and repeat the process.

\subsection{Category 5. Strategies to Improve Computing-Related Career Enrollment}

One of the essential indicators or factors in any educational institution is the enrollment of new students, which, depending on the number of new students, the assignment of resources is done; there are also other apparently intangible factors such as the prestige of the career, school, faculty, or the university itself. The institutions need to carry out some promotion to make public the different career options offered to students. In this category, we show some strategies found in the literature that pretend improve the enrollment in computing-related careers.

Depending on the target student market, various strategies can be used to promote and attract applicants, including social networks, radio, television, e-mail campaigns, on-site workshops, professional fairs or conferences, among others (Asgill et al. 2013; Bowman et al. 2018). From the commercial point of view, to satisfy customers, it is necessary to know them, so that information regarding the characteristics, experiences, expectations, needs, opinions, and desires of students are essential in determining the strategies to be used to have a competitive position in the higher education market (Suárez Zozaya 2013). On the other hand, according to Gutiérrez-Gómez (1999), the problem that students face when choosing a career or determining their vocational preferences is linked to the lack of professional information, justifying that, with an updated information system, they can modify their preferences by choosing another career.

There are no specific computing-related career strategies in the literature to improve this enrollment, so an analysis of engineering-related careers, in general, is presented in this category, so some of the strategies described above we can adapt to augment the students of this careers. In this sense, Tomsk Polytechnic University, through the Elite Engineering Education Programme (EEEP), to attract talented students, provides its prospects with additional training aimed to improving their general and professional awareness to develop their ability to adapt to such a changing engineering environment (Chuchalin et al. 2013). This initiative responds to a series of problems encountered by the Russian education system: (1) educational quality in Russian schools is declining, (2) the most sought-after careers are law, economics, and administration, and (3) engineering graduates do not meet the demands of modern society due to a lack of specialization and interdisciplinary skills. The quality of their program is checked, considering that all graduates have been employed by major industrial companies, research centers or have created their own companies to continue with the development of projects that began at the university.

As Schwartz (2016) points out, it is a necessity for engineering graduates to develop their communication skills; he mentions that students spend much of their careers developing science, 
engineering, mathematics and technological skills, so that at the start of their working life they are unable to communicate their ideas with other colleagues, managers or clients. Likewise, he outlines a strategy that uses in its introductory programming course, which consists of students solving word problems that require further reflection in order to be solved; it mentions that it has succeeded in getting students to present their work in a group and discuss the presentations made, thus improving their students' communication skills.

At the same time, curriculum design focused on the desirable characteristics of the professional is vitally important, especially when this curriculum maintains the same profile through the different educational levels; in the same way, it is essential for teachers to prepare academically in new techno-educational strategies. Concerning the curriculum, Yoo, Pattaparla, and Shaik (Yoo et al. 2016) developed a study plan for the Computing Education Academy (CEA) to increase interest in computer science among high school students, introducing students to fundamental computer concepts and computer programming through hands-on activities. The application of a pre- and post-survey resulted in increased student interest in computing-related areas by presenting a better understanding of computing.

Also, Starodubtseva et al. (2015) describe a technique using an algorithm for the design of two academic master's degree programmes: Mechanical Engineering and Information Technology, based on experience gained from working in European and Russian universities. In their research they address the process of developing the academic program, identifying labor market demand and the list of expected learning outcomes, as well as the list of modules and disciplines needed to include in the curriculum. They make it clear that using a framework for the design of an academic program helps to improve processes and its quality.

On the other hand, in several researches it is recognized that science and technology education should play a more significant role in developing student awareness and improving attitudes towards careers in science and technology (Thouin et al. 2018; Vaino et al. 2015). For instance, in the research of T. Vaino, K. Vaino, and Rannikmäe (Vaino et al. 2015), they designed an optional course for 62 students in the eleventh grade of an Estonian school, with the intention of involving them in developing scientific knowledge, through the integration of various scientific and technological disciplines applied to everyday life, to develop the capacity for responsible decision making about these issues. They applied interviews, in addition to pre- and post- questionnaires, noting that interest in science and technology increased, helping them to understand the diversity of scientific and technological areas, as well as the relationships between them.

\subsection{Category 6. Quality Perception of Engineering Education Programs}

Regardless of the discipline area, the perception of a career, school, teachers, or even facilities can influence a high school student's decision to pursue a degree. In addition, there is a wide range of academic offerings by educational institutions in related disciplinary areas, which can confuse students, so perception would help the student not only to decide on which career to studying, but also where to study it (National Academies of Sciences, Engineering, and Medicine 2018; O'Herrin et al. 2018). In this category, we show some studies that address the quality perception of students about the programs offered.

The University Kebangsaan Malaysia (UKM) conducted a study of undergraduate students' perception of the engineering programs they offer. In this regard, they developed their questionnaire consisting of three sections: (1) demographic survey; (2) reputation of the UKM and its engineering programs; and (3) interest in engineering programs. The questionnaire was distributed to 231 students in the Faculty of Engineering and used the Rasch measurement model to explain the results obtained. The results showed that students recognized that the engineering program they were studying at the time, was the best in Malaysia, and are motivated to pursue a post-graduate degree in engineering (Misran et al. 2013).

It is useful to know what is happening in other disciplines, to mention just one example, in the medical disciplines we have observed that there is a significant concern about the perception that 
students have of these careers. Some of these research works in this discipline are aimed at finding out the reason for the decrease in the number of applications for residency in surgery (Hill et al. 2014), the perceptions and motivations of career selection in anaesthesiology (Kuhn 2014), and the perception and interest in studying nursing careers (Fillman 2015). In the works of Hill et al. (2014), they applied a serie of questionnaires to learn about these perceptions, which served as the basis for individual interviews to conduct the study in depth; with the results they categorized a serie of stereotypes of surgeons: self-confidence, intimidating, competitive, mostly male and requiring many sacrifices. They conclude that strong stereotypes discouraged students from continuing with a surgical career, so they should actively involve medical students to deflect the negative perception that avoids enrollment in surgery. Fillman (2015), also based on the SCCT theory, chose self-efficacy and perception as research variables to understand both perception and interest in nursing careers. They adapted and combined a Career Search and Perceptions of Professional Nursing Questionnaire with web-based 40 questions, finding among other results that media representation of nursing and early career counseling for younger populations should be increased.

In the works of Christensen, Knezek, and Tyler-Wood (Christensen et al. 2014), they study the perception of students of the last two years of High School towards contents and careers related to scientific disciplines, through a semantic survey and a questionnaire of career interests. They found, among other results, that the three most important reasons to be interested in this type of careers are family support, a high motivation of some teacher, and self-motivation for the career.

With regard to students' perception of the quality of private universities in Monterrey, Mexico, the study carried out by Alvarado-Lagunas, Luyando-Cuevas, and Picazzo-Palencia (Alvarado-Lagunas et al. 2015), by means of a semi-structured survey, enabled them to create a model of structural equations, which in turn allowed them to explain the students' perceptions of quality in this type of educational institutions. The results showed that the main factors were: the integral development of their teachers, the use and management of facilities and physical equipment with state of the art technology, and the level of preparation of the teaching personnel.

In another similar study conducted by Alvarado-Lagunas, Morales-Ramírez, and Aguayo-Téllez (Alvarado-Lagunas et al. 2016), but focused on two of the most recognized private universities in northern Mexico, -specifically the Autonomous University of Nuevo León (UANL) and the Monterrey Institute of Technology and Higher Education (ITESM), they found through a similar methodology that the majority of students surveyed in general terms have a positive perception of their respective institutions; whereas for ITESM students it is more important to have modern facilities and innovative technology in the classroom; for UANL students it is more the academic preparation of their teachers.

\section{Conclusions}

In this article we conducted a literature search related to the factors that directly or indirectly influence a student's decision to study a computing-related career; we selected the most representative and engaging documents, analyzed them and determined a series of categories in which to frame the factors found. We illustrated through this documentary research, the importance of knowing and understanding the main factors that affect the demand for university careers in general, and specifically in computing-related careers; while giving the opportunity to identify opportunities and generate possible academic, administrative or government strategies for increasing enrollment in accordance with both, the interests of students and educational policies.

Throughout this analysis, a first conclusion is, that in the knowledge society there are challenges for educators due to a generational change that cannot be avoided, technological advances and educational resources evolve, and each generation has new characteristics to which the teacher has to adapt (Mayes et al. 2015). In the same way, the profile of the teacher plays an important role to face these challenges, so it is a highly recommended that the teacher's profile adjusts to the academic program (Todorescu et al. 2015). 
A second conclusion is that intrinsic motivational factors (such as personality, abilities, expectations, and perceptions), and extrinsic motivational factors (such as socio-economic status, cultural background, school curriculum, attitudes and values of teachers and parents) have a significant influence on both career choices and abandonment (Dahle et al. 2018; Korkmaz 2015; Marra et al. 2012).

Thirdly, we can conclude that facing a technologically globalized world, the academic programs offered by higher education institutions must be innovative and modern, effectively integrating both the new technologies and the tools they provide into the educational process, for integrally developing the students, so that they can incorporate into the labor market to meet the needs of society and industry (Ciolan et al. 2014; Kornienko 2015; Pattnayak and Pattnaik 2016; Zamyatina et al. 2014).

Fourthly, we concluded that although the literature shows only some strategies to increase school demand, it is important to remark that in addition to what was described in fifth category, these are implemented through a series of activities such as sensitization talks, professional fairs, short courses/workshops, programmed visits, advertising in social networks, and so on (Thomassie et al. 2018). Most strategies are aimed to providing candidates with extra training to improve their ability to adapt to the engineering environment (Chuchalin et al. 2013); schedule a series of academic activities to improve communication skills (Schwartz 2016), and develop academic programs according to labor market needs by identifying the expected profile (Starodubtseva et al. 2015). Finally, we established that students' perception of engineering programs plays an important role according to the studies of Misran, Nurhanum, and Sahuri (Misran et al. 2013), as well as with other disciplines such as medical specialties (Fillman 2015; Hill et al. 2014; Kuhn 2014); on the other hand, the perception of the quality of an educational institution according to its human and material resources is also significative (Alvarado-Lagunas et al. 2015).

The fact is that we can see the increase in the enrollment for computing-related careers, as an opportunity for further research, which would explain the phenomenon of low demand for careers described as hard. Far from comparing them to high-demand careers, it is necessary to understand why students prefer less technical careers, even though they may not be better paid. Longitudinal studies can be carried out by applying different strategies at the previous educational levels like workshops, talks by graduates, introductory classes, pre-university courses, induction talks, student exhibitions, open-door universities, among others. On the one hand, to strengthen knowledge, skills, and attitudes, and on the other to increase both intrinsic and extrinsic personal motivation to enable students to choose the right career to study, as well as to enable them to integrate effectively into the educational process of that career.

Author Contributions: W.A.M.-L. and S.T. jointly contributed to the research, selection, and analysis of documents, as well as to the writing of the paper.

Funding: This research received no external funding.

Conflicts of Interest: The authors declare no conflict of interest.

\section{References}

Alexander, Patricia Margaret, Marlene Amanda Holmner, Hugo H. Lotriet, Machdel Matthee, Heloise Pieterse, Saloshana Naidoo, Hossana Twinomurinzi, and Danie Jordaan. 2011. Factors Affecting Career Choice: Comparison Between Students from Computer and Other Disciplines. Journal of Science Education and Technology 20: 300-15.

Alianza FiiDEM, A. C. 2014. Estudio de la Demanda de las Carreras de Ingeniería y de Mejores Prácticas Internacionales sobre Vinculación para la Formación. Available online: https://goo.gl/8R7d7a (accessed on 20 January 2018).

Alvarado-Lagunas, Elías, José Raúl Luyando-Cuevas, and Esteban Picazzo-Palencia. 2015. Percepción de los estudiantes sobre la calidad de las universidades privadas en Monterrey. Revista Iberoamericana de Educación Superior 6: 58-76. 
[CrossRef]

Alvarado-Lagunas, Elías, Dionicio Morales-Ramírez, and Ernesto Aguayo-Téllez. 2016. Percepción de la calidad educativa: caso aplicado a estudiantes de la Universidad Autónoma de Nuevo León y del Instituto Tecnológico de Estudios Superiores de Monterrey. Revista de la Educación Superior 45: 55-74. [CrossRef]

Asgill, Austin B., Craig Chin, Florian Misoc, Simin Nasseri, Adimathara Preethy, Scott Tippens, Randall Emert, and Ali Khazaei. 2013. An Interdisciplinary Strategy for Improving Enrollments in ET Programs. Paper presented at 2013 ASEE Annual Conference \& Exposition, Atlanta, GA, USA, June 23-26.

Álvarez-Lires, Francisco Javier, Azucena Arias-Correa, José Francisco Serrallé-Marzoa, and Mercedes Varela-Losada. 2014. Elección de Estudios de Ingeniería: Influencia de la Educación Científica y de los Estereotipos de Género en la Autoestima de las Alumnas. Revista de Investigación en Educación 12: 54-72. Available online: https: / /goo.gl/6tv46E (accessed on 20 January 2018).

Belanger, France, Tracy Lewis, George Kasper, Wanda Smith, and Vernard Harrington. 2007. Are Computing Students Different? An Analysis of Coping Strategies and Emotional Intelligence. IEEE Transactions on Education 50: 188-96. [CrossRef]

Bernal, César Augusto. 2010. Metodología de la Investigación. Bogotá: Pearson Educación.

Bossart, Jean, and Neelam Bharti. 2018. Ten ways academic libraries can help their departments increase retention of women engineering students. Paper presented at the ASEE Annual Conference and Exposition, Salt Lake City, UT, USA, June 24-27.

Bowman, Nicholas A., Sanga Kim, Laura Ingleby, David Ford, and Christina Sibaouih. 2018. Improving college access at low-income high schools? The impact of GEAR UP iowa on postsecondary enrollment and persistence. Educational Evaluation and Policy Analysis 40: 399-419. [CrossRef]

Burns, Julie Kling. 2002. Opportunities in Computer Careers. New York: McGraw-Hill.

Bussaban, Kanyarat, and Phanu Waraporn. 2015. Preparing Undergraduate Students Majoring in Computer Science and Mathematics with Data Science Perspectives and Awareness in the Age of Big Data. Procedia Social and Behavioral Sciences 197: 1443-46. [CrossRef]

CACEI. 2014. Marco de Referencia para la Acreditación de los Programas de Ingeniería-2014. Available online: https:/ / goo.gl/pKspWe (accessed on 12 May 2018).

CACEI. 2018. Marco de Referencia 2018 del CACEI en el Contexto Internacional (Ingenierías). Available online: https:/ / goo.gl/3UsgFh (accessed on 12 May 2018).

Christensen, Rhonda, Gerald Knezek, and Tandra Tyler-Wood. 2014. Student perceptions of Science, Technology, Engineering and Mathematics (STEM) content and careers. Computers in Human Behavior 34: 173-86. [CrossRef]

Chuchalin, Alexander I., Mikhail A. Soloviev, Oxana M. Zamyatina, and Polina I. Mozgaleva. 2013. Elite Engineering Education Programme in Tomsk Polytechnic University-The way to attract talented students into Engineering. Paper presented at IEEE Global Engineering Education Conference (EDUCON), Berlin, Germany, March 13-15, pp. 1004-8. [CrossRef]

Ciolan, Laura, Anca Petrescu, Camelia Radulescu, and Cristian Bucur. 2014. Training Teachers to Use Digital Resources for the Knowledge Society. Procedia Social and Behavioral Sciences 128: 415-19. [CrossRef]

CONAIC. 2013. Marco de Referencia para la Acreditación de Programas Académicos de Informática y Computación. Available online: https:/ /goo.gl/Eaxk9x (accessed on 12 May 2018).

Contreras, Orlando E., and Ivanhoe Rozo-Rojas. 2015. Teletrabajo y sostenibilidad empresarial. Una reflexión desde la gerencia del talento humano en Colombia. Suma de Negocios 6: 74-83.

Cozzolino, Elizabeth, Chelsea Smith, and Robert L. Crosnoe. 2018. Family-related Disparities in College Enrollment across the Great Recession. Sociological Perspectives 61: 689-710. [CrossRef]

Dahle, Reena, Lori Jockers, Alicia Scott, and Katherine Wilson. 2018. Major in engineering, minor in art: A new approach to retaining females in engineering. Paper presented at the 2017 IEEE Women in Engineering (WIE) Forum USA East, Baltimore, MD, USA, November 30-December 2. [CrossRef]

Declercq, Koen, and Frank Verboven. 2018. Enrollment and degree completion in higher education without admission standards. Economics of Education Review 66: 223-44. [CrossRef]

Del Cid, Alma, Rosemary Méndez, and Franco Sandoval. 2011. Investigación. Fundamentos y metodología. Edo. de México: Pearson Educación. 
Estrada-Danell, Rafael Isaac, Román Alberto Zamarripa-Franco, Pilar Giselle Zúñiga-Garay, and Isaías Martínez-Trejo. 2016. Aportaciones desde la minería de datos al proceso de captación de matrícula en instituciones de educación superior particulares. Revista Electrónica Educare 20: 1-21. [CrossRef]

Fernandes, Gustavo Andrey de Almeida Lopes. 2018. The problem of school enrollment rules: What can be changed in the largest city in Brazil. Revista De Administracao Publica 52: 740-52. [CrossRef]

Fillman, Valentina M. 2015. Career interest, self-efficacy, and perception in undecided and nursing undergraduate students: A quantitative study. Nurse Education Today 35: 251-55. [CrossRef]

Gutiérrez-Gómez, Rubén. 1999. La oferta y la demanda de los egresados de la UAEM: hacia otra perspectiva de la elección vocacional. Tiempo de Educar 1: 31-70.

Hernández-Sampieri, Roberto, Carlos Fernández-Collado, and María del Pilar Baptista-Lucio. 2014. Metodología de la investigación. México D.F.: McGraw-Hill.

Hill, Elspeth J. R., Katherine A. Bowman, Renée E. Stalmeijer, Yvette Solomon, and Tim Dornan. 2014. Can I cut it? Medical students' perceptions of surgeons and surgical careers. The American Journal of Surgery 208: 860-67. [CrossRef]

Hunt, Jennifer. 2016. Why do Women Leave Science and Engineering? ILR Review 69: 199-226. [CrossRef]

Jiang, Suhang, Katerina Schenke, Jacquelynne Sue Eccles, Di Xu, and Mark Warschauer. 2018. Cross-national comparison of gender differences in the enrollment in and completion of science, technology, engineering, and mathematics massive open online courses. PLoS ONE 13: e0202463. [CrossRef]

Kori, Külli, Margus Pedaste, Heilo Altin, Eno Tõnisson, and Tauno Palts. 2016. Factors That Influence Students' Motivation to Start and to Continue Studying Information Technology in Estonia. IEEE Transactions on Education 59: 255-62. [CrossRef]

Korkmaz, Hunkar. 2015. Factors Influencing Students' Career Chooses in Science and Technology: Implications for High School Science Curricula. Procedia Social and Behavioral Sciences 197: 966-72. [CrossRef]

Kornienko, Anna. 2015. University Education in the Development of Knowledge-based Society: Network Technologies of Scientific Research and Cyberscience as Factors of Education Professionalization. Procedia Social and Behavioral Sciences 206: 359-64. [CrossRef]

Kozak, Dražan. 2019. Study Programs in STEM Field in Eastern European Countries vs. Brain Drain. In Advances in Manufacturing Engineering and Materials. Edited by Sergej Hloch, Dagmar Klichová, Grzegorz Krolczyk, Somnath Chattopadhyaya and Lucie Ruppenthalová. Lecture Notes in Mechanical Engineering. Cham: Springer.

Kuba, Radim, Jaroslav Flegr, and Jan Havlíček. 2018. The effect of birth order on the probability of university enrolment. Intelligence 70: 61-72. [CrossRef]

Kuhn, Catherine M. 2014. Perceptions and motivations of career selection in anesthesiology: Do medical students want what our specialty needs? Journal of Clinical Anesthesia 26: 89-90. [CrossRef] [PubMed]

Lee, Minji, Kathaleen Starr-Mitchell, Lara Nunes, Michael Black, and Thomas Schmidt. 2017. MOOCs as facilitator: Online learning and women in STEM. Paper presented at the 2017 International Conference on Engineering, Technology and Innovation: Engineering, Technology and Innovation Management Beyond 2020: New Challenges, New Approaches, ICE/ITMC 2017-Proceedings, Funchal, Portugal, June 27-29, pp. 482-86. [CrossRef]

Mangu, Daniel M., Andrew R. Lee, James A. Middleton, and Jill K. Nelson. 2015. Motivational factors predicting STEM and engineering career intentions for high school students. Paper presented at IEEE Frontiers in Education Conference (FIE), El Paso, TX, USA, October 21-24, pp. 1-8. [CrossRef]

Marra, Rose M., Kelly. A. Rodgers, Demei Shen, and Barbara Bogue. 2012. Leaving Engineering: A Multi-Year Single Institution Study. Journal of Engineering Education 101: 6-27. [CrossRef]

Mayes, Robin, Gloria Natividad, and J. Michael Spector. 2015. Challenges for Educational Technologists in the 21st Century. Education Sciences 5: 221-37. [CrossRef]

Misran, Norbahiah, Sarifah Nurhanum, and Syed Sahuri. 2013. Undergraduate Student's Perception towards Engineering Program at UKM. Procedia Social and Behavioral Sciences 102: 110-15. [CrossRef]

Muñóz, Mirna, Adriana Peña, Jezreel Mejía, and Graciela Lara. 2016a. Actual State of the Coverage of Mexican Software Industry Requested Knowledge Regarding the Project Management Best Practices. Computer Science and Information Systems 13: 849-73. [CrossRef]

Muñóz, Mirna, Adriana Peña, Jezreel Mejía, and Graciela Lara. 2016b. Coverage of the university curricula for the Software Engineering industry in Mexico. IEEE Latin America Transactions 14: 2382-88. [CrossRef] 
National Academies of Sciences, Engineering, and Medicine. 2018. Assessing and Responding to the Growth of Computer Science Undergraduate Enrollments. Washington, DC: The National Academies Press. [CrossRef]

Ngamkajonviwat, Anuchit, Wasant Atisabda, Ophat Kaosaiyaporn, and Chidchanok Churngchow. 2015. Instructional System Design for Worker Education in Multicultural and Knowledge-based Society. Procedia Social and Behavioral Sciences 174: 2355-60. [CrossRef]

O'Herrin, Keith, Susan D. Day, P. Eric Wiseman, Curtis R. Friedel, and John F. Munsell. 2018. University student perceptions of urban forestry as a career path. Urban Forestry and Urban Greening 34: 294-304. [CrossRef]

Oktaba, Hanna, and Ana Vázquez. 2008. MoProSoft ${ }^{\circledR}$ : A Software Process Model for Small Enterprises. In Software Process Improvement for Small and Medium Enterprises: Techniques and Case Studies. Edited by Hanna Oktaba and Mario Piattini. Hershey: IGI Global, pp. 170-76.

Olmedo-Torre, Noelia, Fermín Sánchez Carracedo, M. Núria Salán Ballesteros, David López, Antoni Perez-Poch, and Mireia López-Beltrán. 2018. Do female motives for enrolling vary according to STEM profile? IEEE Transactions on Education 61: 289-97. [CrossRef]

Oo, Bee L., Sirui Li, and Leshui Zhang. 2018. Understanding female students' choice of a construction management undergraduate degree program: Case study at an australian university. Journal of Professional Issues in Engineering Education and Practice 144: 05018004-1-8. [CrossRef]

Pattnayak, Jui, and Sabyasachi Pattnaik. 2016. Integration of Web Services with E-Learning for Knowledge Society. Procedia Computer Science 92: 155-60. [CrossRef]

Pažur Aničić, Katarina, Blaženka Divjak, and Krunoslav Arbanas. 2017. Preparing ICT Graduates for Real-World Challenges: Results of a Meta-Analysis. IEEE Transactions on Education 60: 191-97. [CrossRef]

Rodríguez Amaya, Laura, Tania Betancourt, Kristina Henry Collins, Orlando Hinojosa, and Carlos Corona. 2018. Undergraduate research experiences: Mentoring, awareness, and perceptions-A case study at a Hispanic-serving institution. International Journal of STEM Education 5: 9. [CrossRef]

Royal Spanish Academy. 2014. Diccionario de la Lengua EspaÑola (23.a ed.). Available online: http:/ / dle.rae.es / ?id=SX9HJy3 (accessed on 10 January 2018).

Schunk, Dale H., Judith R. Meece, and Paul R. Pintrich. 2008. Motivation in Education: Theory, Research, and Applications. Upper Saddle River: Pearson/Merrill Prentice Hall.

Schwartz, Jeffrey L. 2016. Preparing high school students for college while training engineering students in soft skills. Paper presented at IEEE Integrated STEM Education Conference (ISEC), Princeton, NJ, USA, March 5, pp. 12-115. [CrossRef]

Stanko, Tanya, Oksana Zhirosh, and Dmitry Krasnikhin. 2014. Why girls with an interest in IT in high-school do not choose an IT career. Paper presented at International Conference on Interactive Collaborative Learning (ICL), Dubai, UAE, December 3-6, pp. 131-37. [CrossRef]

Starodubtseva, Daria V., Oxana M. Zamyatina, and Yulia O. Goncharuk. 2015. Curriculum design and development of master's educational programs in IT area (through the example of international development of master programs Applied computing and Product life cycle technological process efficiency of TEMPUS SUCCESS and ACES projects). Paper presented at International Conference on Interactive Collaborative Learning (ICL), Florence, Italy, September 20-24, pp. 393-96. [CrossRef]

Suárez Zozaya, María Herlinda. 2013. Los estudiantes como consumidores: Acercamiento a la mercantilización de la educación superior a través de las respuestas a la Encuesta Nacional de Alumnos de Educación Superior (ENAES). Perfiles Educativos 35: 171-87.

Thomassie, Rachal E., Kathryn Kirsch, Eric R. Marsh, and Timothy J. Jacobs. 2018. High-Enrollment Mechanical Engineering Programs Meeting the Challenge of Career Advising Through a Seminar Course. Paper presented at 2018 ASEE Annual Conference \& Exposition, Salt Lake City, UT, USA, June 24-27.

Thouin, Mark F., William E. Hefley, and Srinivasan Raghunathan. 2018. Student attitudes toward information systems graduate program design and delivery. Journal of Information Systems Education 29: 25-36.

Tobón, Sergio. 2016. Methodology of Curricular Management: A Socioformative Perspective. Lake Mary: Kresearch. Available online: https:/ / cife.edu.mx/recursos/2018/09/10/2411/ (accessed on 25 November 2018).

Tobón, Sergio. 2017. Essential Axes of Knowledge Society and Socioformation. Mount Dora: Kresearch. Available online: https:/ / cife.edu.mx/recursos/2018/09/03/essential-axes-of-knowledge-society-and-socioformation/ (accessed on 25 November 2018). 
Tobón, Sergio. 2018. Conceptual Analysis of the Socioformation According to the Knowledge Society. Knowledge Society and Quality of Life (KSQL) 1: 9-35. Available online: http:/ / fisod.org/ksql/index.php/ksql (accessed on 25 November 2018).

Todorescu, Liliana Luminita, Anca Greculescu, and Maria Monica Popescu-Mitroi. 2015. Engineering Students' Career Choice and the English Teacher's Profile in Romanian Higher Education. Procedia Social and Behavioral Sciences 197: 201-6. [CrossRef]

Vaino, Toomas, Katrin Vaino, and Miia Rannikmäe. 2015. Enhancing Students' Interests in Science and Technology Related Careers Through a Specially Designed Optional Course. Procedia Social and Behavioral Sciences 177: 331-35. [CrossRef]

Vali, Ilie. 2013. The Role of Education in the Knowledge-based Society. Procedia Social and Behavioral Sciences 76: 388-92. [CrossRef]

Villegas Téllez, Rodrigo, David Antonio Torres, Krystel Palacios Gutiérrez, and Fernando De Los Reyes. 2015. Proyección de Matrícula para el Análisis de la Infraestructura de Programas Académicos en Vía de Acreditación. Tecnología Educativa-Revista CONAIC 2: 44-56.

Webster, F. 2006. Theories of the Information Society. Abingdon: Routledge.

Wright, Geoffrey Albert. 2017. Engineering attitudes: An investigation of the effect of literature on student attitudes toward engineering. International Journal of Technology and Design Education 28: 653-65. [CrossRef]

Yoo, Wook Sung, Spoorthi Raghunandan Pattaparla, and Sameer Ahamed Shaik. 2016. Curriculum development for computing education academy to enhance high school students' interest in computing. Paper presented at IEEE Integrated STEM Education Conference (ISEC), Princeton, NJ, USA, March 5, pp. 282-84. [CrossRef]

Zamyatina, Oxana M., Polina I. Mozgaleva, and Kseniya V. Gulyaeva. 2014. Elite engineering education programme development based on CDIO standarts. Paper presented at International Conference on Interactive Collaborative Learning (ICL), Dubai, UAE, December 3-6, pp. 919-23.

(C) 2018 by the authors. Licensee MDPI, Basel, Switzerland. This article is an open access article distributed under the terms and conditions of the Creative Commons Attribution (CC BY) license (http:/ / creativecommons.org/licenses/by/4.0/). 